\title{
Media discourse on women in politics: The first Muslim woman of colour in US Congress
}

\author{
D. S. Cheshmedzhieva-Stoycheva
}

Konstantin Preslavsky University of Shumen, 115, Universitetska str., Shumen, 9700, Bulgaria

For citation: Cheshmedzhieva-Stoycheva, D.S. (2020). Media discourse on women in politics: The first Muslim woman of colour in US Congress. Media Linguistics, 7 (4), 490-500.

https://doi.org/10.21638/spbu22.2020.408

This analysis is a part of a bigger study on the presentation of Muslim women in the media. The focus here is on Ilhan Omar, the first Muslim Somali-born woman in American Congress, and more specifically on the latest publications on Omar which delve into her personal family life and the alleged marriage she has entered into with her brother, so that she can provide him with a green card for the USA. The topic presents a cross-section of several major fields of study such as feminism, media studies, and culture studies as the emphasis is on the biased media representation intended to diminish the real worth of a woman politician who is a carrier of several different identities, namely: gender, religious, ethnic, and class. The corpus for this study consists of 42 articles published in various online media over a period of four months from January 2020 to April 2020. The paper argues that first, the presentation Ilhan Omar enjoys is gendered and second, that it is subjected to the stereotypical image of Muslim women as submissive and silent, being of a lower status than men, especially in a male-dominated field such as politics. In addition, it is also argued that although Omar breaks the existing stereotypes of Muslim women, the way media present her actually reinforces the preconceived ideas she refutes. To prove the above, the main methods of analysis applied are Critical Discourse Analysis along with Multi-modal analysis when the non-verbal part of the presentation on the image is concerned.

Keywords: media discourse, Muslim women, politics, CDA, feminism.

\section{Introduction}

Ilhan Oman is the first of two Muslim women who managed to find their place in American Congress in 2019 [see Black Women in Politics 2019; Ilhan Omar 2020]. She is the representative of the district of Minnesota and apart from being religiously different she is also a Somali-immigrant and therefore described as "a woman of colour".

Only this short part of her biography is enough to single her out as a trail-blazer and a political pioneer in the generally white Christian male dominated world of politics. The fact that she got a seat in Congress means that the people of her district supported her as a person and the ideas she stands for and in this respect she could also be defined as a public figure and in a way a role model. However, as difference is more easily noticed than uniformity, her image is sure to provoke interest and be subjected to such, reaching to the degree of scrutiny. It is generally known that politicians are also closely watched by their political opponents as well as by the media. As Karen Boyle [Boyle 2020] shares in

(C) Санкт-Петербургский государственный университет, 2020 
a video, media have a huge role to play in the presentation of women in politics as they choose what aspect of the politics to share and how to present the image of that politician: "they can represent female politicians in a very deep way or in a shallow way. And what tends to happen is that they will look at the politician's shoes not their views. So you might find that a male politician gets their policies reported on and a female politician gets her haircut reported on" [Boyle 2020].

For almost four months in $2020^{1}$ (Jan. 2020 - April 2020) it was exactly the "shoes and not views" [Boyle 2020] of Ilhan Omar that the media focused on. For the purposes of this study a selection of 42 articles published in various online media on her alleged marriage to her brother have been analysed, disregarding the various picture only reports that have also made their way in the public sphere.

The paper marks an attempt at analysing the media language on women politicians taking as an example a very personal matter that gets reported. And as it is obviously a case of inequality in terms of the topic chosen for presentation, the study falls within the premises of feminism understood in a very generic sense as "a movement to end sexism, sexist exploitation, and oppression" [Hooks 2015: vii]. Yet, as Ilhan Omar provides a topic in which issues of gender, ethnicity, religion and even class intersect, the paper also marks a case of intersectionality as put forward by Crenshaw [2016].

\section{Background studies}

The topic, as already stated, is multifaceted and can generally be viewed within the field of media studies, feminism and politics. Media as the trend setters in society play a considerable role in establishing the image of a public figure, however, they generally serve the powerful elite and present the biased views of those mighty few [van Dijk 1991]. Looking at the issue from a feminist point of view, Adcock [Adcock 2010] adds that it is mostly men who decide what gets published as the media and society in general are male dominated. Thus, the presentation Omar receives is also subjected to the policy of the particular newspapers towards people of colour, and more specifically women of colour, as well as of those who are religiously and politically different ${ }^{2}$ [Who makes the news 2015; Black Women in Politics 2019].

The latter is further supported by Haddjieri [Haddjieri 2019] who states that "[w] omen in the media are often under-represented and portrayed in stereotypical ways" although the MeToo movement has somewhat changed that trend [see also Boyle 2019], their image is still gendered [Adcock 2010; Garcia-Blanco \& Wahl-Jorgensen 2011; Campus 2013; Meeks 2013; Joly \& Wadia 2017] in a way that it is their physical appearance or looks, rather than their opinion or ideas, that are presented [see Acker 2003; Campus 2013; Ross

${ }^{1}$ Actually, the attacks at Omar Ilhan's personal have been going on and off ever since 2016 when she gained some prominence on the political scene in the States. At the beginning of 2020, however, the attacks have been incessant for approximately four whole months.

2 According to the data provided by the Global Media Monitoring Project the coverage of women in the print, media and radio in the USA which shows that for 2015 there has been $25 \%$ on women vs. $75 \%$ on men [Who makes the news 2015: 11; see also Haraldsson \& Wängnerud 2019: 525].

${ }^{3}$ In the same line of thought, Sanbonmatsu [2002: 20] argues that "voters employ gender stereotypes when they evaluate candidates" and states that women politicians are endowed with more feminine traits such as compassion, for example, while male candidates with masculine traits and better at handling "crime, defense and foreign policy issues" [see also Campus 2013; Ross 2017; Boyle 2020]. 
2017; Boyle 2019; Boyle 2020]. Ross [Ross 2017: 56] calls such type of presentation "willful misinformation" as the focus is on what is sensational and easy to grasp by the audience.

At the same time, it has been upheld that the women who are different in a way achieve the status of celebrities and are under close scrutiny by the media and their political opponents [see Roth \& Huff 2019] and that those "notable" women usually stand out it some way "not in line with society's prescription of what women 'should' and 'should not' do" [Made 2008: 11]. Adcock [Adcock 2010] in her turn states that the presentation on women politicians focuses on different topics which are more personal than the political ones and the tone used is often negative [see also Ross 2017: 57] especially if it is believed that they have done something morally or legally wrong 4 . The latter applies to the interest shown to the alleged marriage fraud committed by Omar.

Everything mentioned so far sets the background for the way Ilhan Omar has been presented by the media.

The Congresswoman representing Minnesota is a carrier of double otherness: on the one hand, she is a woman in a field considered a boyzone [see Ross 2017: 51], while on the other, she is also an ethnic and religious other as she is a Somali immigrant and a Muslim, therefore she can be described as a Muslim black female in a white Christian male dominated sphere of politics. Actually, Ilhan Omar defines herself as an "intersectional feminist" [Weingarten 2020] as her image is a combination of different aspects conducive to the exhibition of inequality, i.e. on the level of gender, religion, status, and ethnic background [see also Joly \& Wadia 2017: 25] and we cannot consider one or the other, but all of them because they mutually constitute and are constitutive of each other [Ward 2016].

Being a Muslim woman, and actually the first of the two Muslim women elected to be members of the congress, is a formula sure to get the media attention to Omar [see Ross 2017: 58]. In addition, Ilhan Omar has broken the mold and can be seen as an "agent of change" [Ross 2017: 58] as she has defied some of the existing stereotypes associated with Muslim women, i.e. the idea of the submissive, silent and invisible Muslim woman [Cheshmedzhieva-Stoycheva 2018: 172] as being involved with politics makes her stand out and she is everything but silent or invisible.

\section{Research methods}

As the subject at hand is mostly associated with unjust practices or bias in the media, the main method of analysis applied is Critical discourse analysis viewed as "a democratic approach which is highly influenced by the context and takes ethic stance on social issues with the aim of improvement of society" [Huckin 1997: 78]. In addition, as the study focuses on the non-verbal presentations used in media publications and the effects they achieve, Multi-modal analysis [O’Halloran 2006] has also been applied.

\section{Analysis}

The corpus of analysed articles focuses on one particular aspect of Omar's life, namely a marriage which she does not want to provide more information on. Coinciding with the idea that she has acquired the status of celebrity and is followed by the media in every step

${ }^{4}$ Donatella Campus [2013: 52] discusses the double binds women political leaders find themselves constrained by: on the one hand, being too feminine is a setback, on the other, being too masculine and assertive is not viewed as an asset either. 
of the political way she takes, she has been scrutinised by her political opponents and they have sensed something they can use against her because of a lack of clarity and also due to the high ethical charge it carried for her as a person and a political representative of a whole state and a community.

It should be highlighted that Ilhan Omar is a Somali immigrant who has received American citizenship when she was very young. However, she has stayed in Minneapolis - a city which is characterised with a big Somali minority. In addition, she is overtly Muslim, as she is always with a typical head cover - a turban or a hijab. All this makes her very visible and standing out in Congress and it is not perchance that all articles feature a picture of her either with a mike, in front of a crowd, behind a bench, or in an explanatory mode, thereby juxtaposing and at the same time mixing in a way her political and personal identity. The juxtaposition comes as a result of the discrepancy in the thematic fields employed - politics and personal life, while the concoction, or mixture, is due to the intersectionality in the image of Omar where obviously one aspect cannot be detached from the other as she brings her gender, religious, ethnic, and class identity into politics.

In addition, had there been more personal photos, with her family for example, the suggestions might have been pointed at the human part of her being, namely that people do make mistakes and that nobody is perfect and safe. Family photos would also have created a more amiable atmosphere and image of Ilhan Omar who is a mother of three. Actually, in most of the articles where her accuser, Osman, is presenting his story about the incestuous marriage, the photos usually include her and her husband Ahmed Hirsi or the two of them, sometimes with her main accuser Abdihakim Osman to prove the veracity of his statement that he was their friend to whom they confided the truth.

A generalised account of the issue at hand as provided by Ilhan Omar herself in 2016 is as follows:

1) She married her first husband, Ahmed Hirsi, in an Islamic faith ceremony in 2002 when she was 19, however, there was no legal marriage certificate.

2) Omar and Hirsi split in 2008 in their Muslim tradition.

3) Omar legally married her second husband, Elmi, in 2009.

4) Elmi and Omar separated in 2011 without a legal divorce. Elmi moved back to London.

5) Omar and Hirsi got back together in 2012 and had their third child.

6) Omar officially divorced Elmi in 2017 and legally married Hirsi in 2018.

The provided outline of events clearly marks the intersection of the religious (Muslim) and the civil (American) part of Ilhan's private life as the account explicitly mentions a marriage in the Muslim tradition, which, however, is not recognized in secular society, thereby, it is not considered legal by the wider public. However, this was not the aspect of her life that attracted media attention the most, but rather her second, civil marriage.

Looking at the articles published on the topic, we can clearly distinguish the main actors involved in the issue, namely Omar as the leading protagonist, Ahmed Hirsi - the man she married in a Muslim ceremony in 2002, Ahmed Nur Said Elmi - allegedly a brother whom she married in 2009, and finally Abdihakim Osman - the "friend" who spread the news of her alleged fraud. Based on the significance of the participants in the scenario, Ilhan Omar has naturally received highest attention and her name appears 584 times in all articles. It should be noted though that journalists have never ventured to 
talk about her using only her first name - a fact which shows some respect. First name address has been used by her spokesman and by Osman when he shared the story to signify their closeness to the Congresswoman.

In addition, the name of the Representative of Minnesota is present in all analysed publication's headlines. Regardless of the fact that, as stated above, the topic has brought media attention back in 2016 and has been also brought up by President Donald Trump in 2019, and despite the fact that there is no hard evidence to confirm the claims made by Osman, six of the headlines foreground her name and the issue in the form of a statement, making it sound definitive: (1) "Ilhan Omar accused of marrying brother by old friend" /h/ (DailyMail/ 20.02.2020) or foreground the accuser: (2) "Somali community leader says Ilhan Omar married her brother" (FoxNews/ 21.02.2020), however, there is a group of articles which actually focus on the doubt of the whole story using an interrogative construction, e.g. (3) Did Ilhan Omar marry brother to get him green card? (NewGreekTV/ 24.02.2020), and there is still a third group of articles which feature the emphatic "did" in their structure in order to highlight the veracity of the illegal marriage, e.g. (4) EXCLUSIVE: Ilhan Omar DID marry her brother and said she would 'do what she had to do to get him "papers" to keep him in U. S.', reveals Somali community leader /h/ (DailyMail/ 20.02.2020). The use of caps as a way of virtual shouting and probably indignation and as an attention grabber has been used by several of the newspapers as a way of putting significance on the matter and to mark it as high priority. In order to support the veracity behind the accusations, the "friend" who disclosed the information on Omar and actually was the initiator of the whole case is described as a "Sommali community leader". At the same time, only one of the analysed articles mentions the significance of different clans in the community: (5) Osman is a member of the Dhulbahante clan, many of whom resent the Majeerteen ${ }^{5}$ for allegedly lording it over them for too long. 'The Majeerteen think they're royalty', one Somali leader said. (DailyMail/ 16.03.2020) and this explanation gives a motive for the possible fabrication of said news. As stated by Scruggs [Scruggs 2012], Somalis are "patrilineal", which means that "they trace their lineage through the male" [Scruggs 2012: 223]. Further, he says that "Somali law acknowledges the husband's authority over his family", although women could have a say in some matters related explicitly to them. This speaks of a patriarchal society where the male figure is considered dominant. The rise and prominence of Omar might be the reason for Osman's grudge and the information he has presented.

Furthermore, looking into Somali culture and especially into marriage, Scruggs [Scruggs 2012: 227] states that polygamy as well as cross-cousin marriages are frequently practiced in that community. Naturally, polygamy is male-dominated as there is one single man marrying up to four different women at a time, which in the case of Ilhan Omar is reversed, as allegedly she has been co-habitating with two men over a particular stretch of time, which for someone living solely within the confines of American culture is difficult to grasp and accept. In this respect, bringing up the topic itself is gendered, because if it had been a man of that community, the polygamy (though not proven yet) would most probably have been viewed as normal.

In addition, talking about the support one of the friends of Omar was seeking from members of their clan against the slurs of Osman, the Daily Mail explains that (6) "Ali

${ }^{5}$ Ilhan Omar is said to be a descendant of that particular clan. 
describes herself as Omar's aunt, but sources say the two are not blood relations, merely members of the same clan" (DailyMail/ 16.03.2020). This is reminiscent of the use of kin terms in some cultures which do not necessarily denote relations by blood, but closeness and difference in age. Following this line of thought and taking into consideration that Osman speaks through an interpreter, it might also well turn out that Elmi is not a real brother to Ilhan Omar but merely a member of her clan who is younger than her but whom she feels close. Thus, the whole idea of an incest which has shocked Omar's political and personal opponents and which has prompted this gendered presentation might simply lie on an inconsistency in translation. Furthermore, as stated in many of the analysed articles, the whole idea about the incest was provoked by publications in the social media which have with time been deleted and remained unproven.

In modern societies, however, people are more open and although sexual intercourse between closely related people is still not widely acceptable and considered sin in Christian tradition, it is not as grave a misconduct as murder or fraud for example. Sexual relations, if performed willingly by both partners, concern only the two people involved in them, while fraud is something that can affect the wider society and immigration or marriage fraud is considered a felony.

In order to stress on the severity of the deed, it is primarily in the headlines describing the possible felony that the status of Ilhan Omar is explicitly mentioned: (7) FBI Investigating Claims That Rep. Ilhan Omar Married Her Brother To Get Him To U.S./h/ (NY Magee, EURweb.com/ 28.01.2020); (8) FBI Investigating Whether U.S Muslim Congresswoman Ilhan Omar Married Her Own Brother To Help Him Secure A Green Card /h/ (Swarajya/ 28.01.2020).

The significance of the case is increased, on the one side, through the involvement of FBI, while on the other, by the fact that it features a high official. Example (8) sounds even stronger as it attributes the felony to a woman who is one of a kind - the US Muslim Congresswoman - someone of authority who has betrayed the trust bestowed on her by her constituents. The latter idea is also found in another example: (9) Finally. The Feds - including ICE - appear to be investigating Rep. Ilhan Omar. /h/ At least three departments are reviewing what could be the worst-ever crime spree by an elected US official /sh/ (TheBlaze/ 16.01.2020). The colloquial style and the search for sensation in the choice of wording of these headline structures is obvious. The attempt at exaggeration of the case is also easily noticed as the severity of the act stands in contrast with the indecisive "appear to be investigating" (suggesting that it is not sure whether they truly are). The same uncertainty is felt through the use of derivatives of "alleged" (used 11 times) and of "suggest" (4 times) in various articles to define different aspects of the whole story. In addition, it is interesting that when talking about evidence some of the newspapers use the unconvincing (10) "a source with knowledge of the event said" (TheNYPost/ 26.01.2020).

Still though, the idea of a crime is linked with punishment which is already something very serious and has been mentioned in seven of the articles using similar wording: (11) Anyone found guilty of committing marriage fraud faces up to five years in jail and a fine of up to $\$ 250,000$ (TheSun/ 17.03.2020). The expression is suggestive of the policy of Zero tolerance [Torronen 2004] which postulates application of the law as it is, regardless of the status of the perpetrators and it sounds as if it is sure that Ilhan Omar will be convicted. 
Two of the newspapers mark the use of explicitly gendered language in their presentation of Rep. Ilhan Omar: (12) Ms Omar, a mum-of-three won a Minnesota seat in the House of Representatives in November 2018, becoming the first Somali-American legislator in the US. (TheSun/ 17.03.2020); (13) The 38-year-old's complicated personal life has been the subject of enduring scrutiny since she was sent to Congress at the 2018 midterm elections. In October, the mom-of-three filed for divorce from husband Ahmed Hirsi after The Post exclusively revealed allegations she was having an affair with DC political consultant Tim Mynett. (TheNYPost/ 26.01.2020).

Foregrounding her social role as a mother makes the implicit suggestion that the role of Omar is primarily as a woman and a mother which stereotypically would not position her in the male dominated world of politics, thereby, the presentations imply that her place is in her home and not in Congress.

Still, she is in Congress and although the first Muslim Somali-American congresswoman, she is by far not the only one: (14) "Ms Omar, 38, the representative for Minnesota, has become well known after Donald Trump's attacks ${ }^{6}$ on her and a group of fellow left-wing congresswomen known as The Squad. (TheSun/ 17.03.2020). Some of the other descriptors used for Omar include: (15) 'Squad' congresswoman Ilhan Omar (DailyMail/ 20.02.2020) as well as (16) the Minnesota freshman representative (InternationalBusinessTimes/ 21.02.2020), which was used three times, along with "a freshman congresswoman", and "a freshman lawmaker" all focusing on her status of a person who stands for a whole state and is actively involved in making laws ${ }^{7}$, but also on the fact that she is a novice in the field, having spent only one year in Congress. The context these phrases were used in, however, is only related to the allegations of marriage fraud which in a way highlights the severity of the assumed crime. At the same time, "freshman" might be considered in a way diminishing as her personal track record shows that she has been involved in politics for quite some time and the fact that in 2016 she became "the first Somali-American, Muslim legislator in the United States" [Ilhan Omar n.d.] should not be underestimated.

The description "Squad congresswoman" 8 has been used five times by the media along the definition of the people included in this unit: (17) "Omar is running for a second term in Congress - where she has aligned herself with fellow leftist first-term congresswomen Alexandria Ocasio-Cortez of New York, Rashida Tlaib of Michigan and

${ }^{6}$ As reported by The Business Insider on October 7, 2019, as well as in several other newspapers, it turns out they are all a nuisance to President Trump who has told them jointly to "go back and fix the broken and crime-infested places from which they came" - a generalization of their background which does not apply to all of them as it is only Omar who is born outside the US, however, it has led to the crowd at a Trump campaign rally in North Carolina chanting "send her back" which in itself is biased and shows intolerance even racism towards those culturally different running at a highest level.

${ }^{7}$ As becomes obvious from her page "In her first year in office, she successfully passed 16 bills and amendments through the U.S. House of Representatives. Ilhan introduced the Student Debt Cancellation Act to end the student debt crisis, Homes for All legislation to end the homelessness crisis, and legislation to tackle child hunger by making school meals universal. She also co-sponsored the No Ban Act to combat Donald Trump's xenophobic Muslim Ban, successfully pushed to extend DED status for the Liberian community in Minnesota, and introduced a War Powers Resolution to prevent war with Iran" [Ilhan Omar n.d.], so she has not wasted her time on personal life only.

${ }^{8}$ The same has been observed by Roth and Huff [2019] as well as by Weingarten [2020], who also adds the description "The Freshmen Congressional Renegades" which actually generalise them as a group and attribute some common features to the four of them. 
Ayanna Pressley of Massachusetts in the so-called 'Squad.' (DailyMail/ 20.02.2020). As stated above, this term is generalising as it attributes equal qualities to the four women it refers to - they all support left-wing politics and they are all culturally different and now they are singled out through a term assigned exclusively to them.

Analysing media coverage, feminist studies proclaim that women's voices in the media are not generally heard as they are usually outnumbered by their male counterparts (journalists, interviewees, opponents) [see Campus 2013; Who makes the news 2015] and are not viewed as significant. In the analysed articles Ilhan Omar gets talked about quite a lot, which is obvious from the number of times her name is mentioned in its various forms and alongside its various descriptors, however, the words she herself has uttered as a comment on the accusations and which got published are few and lack variety: (18) "absurd and offensive" (CityPages/ 27.01.2020) or (19) "baseless, absurd rumors" (DailyMail/ 20.02.2020). The two other times when she was quoted more extensively provide her rejection of the claims made by her accuser: (20) "If someone was asking me, do I have a brother by that name, I don't," Omar told the Star Tribune. "If someone was asking ... are there court documents that are false ... there is no truth to that". (CityPages/ 27.01.2020) and her response to a challenge posed by one of her opponents to sue the media that have published the allegations: (21) Omar tweeted back, "Bring it on. Enemy collaboration: Character Assassination of Ilhan Omar - tabloid brainwashing saga continues - HUMANS 4 HUMAN RIGHTS”. (ClarionProject/ 23.02.2020). The last quote shows her resolution as well as the fact that she would not waver at a challenge. Her words, at the same time, stress on the sensationalism sought by the newspapers.

The group of analysed publications feature only one article which is supportive and defending Rep. Ilhan Omar: (22) Minnesota doesn't deserve Ilhan Omar /h/ The majority of Trump-idolaters criticize Islam for not allowing women to choose who they wish to marry /sh/ (TheSpectator/ 23.02.2020). Godfrey Elfwick plainly shows the narrow-mindedness and bigotry expressed by Trump's supporters who, as he states, "constantly pour scorn and condemnation over the idea of forced marriages, but the moment a strong independent Muslim woman destroys that stereotype and marries her brother out of CHOICE, they condemn her for it. This proves that their concern-trolling exists purely to castigate those who think differently to them, and as we all know, Trump supporters despise anyone who has a different opinion or way of life." (TheSpectator/ 23.02.2020). Although it is self-evident, the article clearly confirms the fact that Ilhan Omar's presence on the American political scene is significant as it breaks the established stereotypes of what it is to be a Muslim, a woman, a Muslim woman, a Muslim politician, and a Muslim woman politician. Opposing the elite takes guts and Congresswoman Omar has proved that she does not shy away from challenges and could remain silent rather than fan further conspiracies when matters irrelevant to her career and work are brought up just to shake her and insult her.

\section{Results}

The analysis on the selected number of articles on Ilhan Omar clearly shows that the choice of her personal life as a focus of presentation is gendered as readers are lured into what is sensational, though unproven, and not to the significant steps she has taken as a Representative of Minnesota. In addition, the media have decided to pay attention to 
rumours and unfounded claims made by a person who has been led by unknown motives. What is more, the cultural aspect of the whole situation has not been delved into, which is a disregard to Ilhan Omar's intersectional identity.

It has also been found out that the media employ strategies such as the use of colloquial style, caps, and descriptors, such as "a mom-of-...", focusing on the female part of her identity and her social role, along with her political status to create interest and sensation. The gendered descriptors, on the other hand, are used to suggest that the place of a woman is not in politics but rather in her home with her family, which is the reincarnation of an old-fashioned gender stereotype.

Furthermore, although the media has shown some respect by using the full name of the Congresswoman rather than referring to her by her first name only, Ilhan Omar is presented as part of a group of women representatives following the same line of politics which in a way generalises her image and deprives her of her own identity as the first Somali-American Muslim Congresswoman. Last but not least, the voice of Omar is silenced and just few of her real words are quoted.

\section{Conclusion}

As a conclusion it can be stated that the main focus of the articles is not so much on the immigration fraud that might have ensued of the whole marriage, but on the fact that it was allegedly her brother whom she married. In addition, rather than focus on her real aptitude as a politician and her agenda, such as to champion human rights, criticize Israel, and challenge Trump administration's immigration policies, the media decide to focus on Ilhan Omar's personal life reiterating several times one and the same statement, i.e. Ilhan Omar married her brother, in different forms: as a statement, as a reconfirmed statement and as a question when there is some doubt about it.

The discrepancy between the verbal and the non-verbal part of the articles lies mainly in the political vs personal life divide as most of the newspapers use pictures of Ilhan Omar talking or explaining something obviously in front of an audience as she is sometimes behind a bench, or with a mike, or explaining something which is evident from the gestures of her hands. This contrast in presentation might be aimed to remind people that she is a representative who stands for a whole community, thereby she is accountable for her actions and thus emphasise the severity of the possible misconduct.

Based on the information provided so far, it can also be concluded that the articles on the one hand, attribute to Omar qualities usually associated with Muslim men, i.e. she is the one who initiates the marriage, or polygamy, she is the one who acts, rather than the one who stands on the side and is submissive, while on the other, they smear her image of a Muslim and a politician by accusing her of breaking the law and possibly hiding information that could expose her fraudulent nature further.

And finally, spending so much time on Omar's personal life, rather than on her lawmaking skills, and presenting scarce examples of her real words, thereby, silencing her, the media place her in the subjugated position of someone talked about, but not heard of or listened to, which confirms the idea of biased representation of her image in the media as well as of the passivity of Muslim women which is a partial reaffirmation of the existing stereotype which she actually refutes. 


\section{References}

Acker van, E. (2003). Media representations of women politicians in Australia and New Zealand: High expectations, hostility or stardom. Policy and Society, 22 (1), 116-136. https://doi.org/10.1016/S14494035(03)70016-2.

Adcock, Ch. (2010). The politician, the wife, the citizen, and her newspaper, Feminist Media Studies, 10 (2), 135-159. https://doi.org/10.1080/14680771003672254.

Black women in American politics. (2019). Center for American Women and Politics (CAWP).

Boyle, K. (2019). MeToo, Weinstein and Feminism. Palgrave MacMillan.

Boyle, K. (2020). Page from Gender Representation in the Media University of Strathclyde. Retrieved from https://www.futurelearn.com/courses/gender-and-the-media/2/steps/729982.

Campus, D. (2013). Women political leaders and the media. Houndmills. DOI 10.1057/9781137295545.

Cheshmedzhieva-Stoycheva, D. (2018). Framing Muslims in the Bulgarian and the British media discourse. Shumen: Konstantin Preslavsky University Press.

Crenshaw, K. (2016). TEDWomen 2016. The urgency of intersectionality. Retrieved from https://www.ted. com/talks/kimberle_crenshaw_the_urgency_of_intersectionality.

Dijk van, T. A. (1991). Racism and the press. London: Routledge.

Garcia-Blanco, I., \& Wahl-Jorgensen, K. (2012). The discursive construction of women politicians in the European Press. Journal Feminist Media Studies, 12 (3). 422-441.

Haddjieri, S. (2019). Women in Politics and their Representation in Media. NAOC.Retrieved from http:// natoassociation.ca/women-in-politics-and-their-representation-in-media/.

Haraldsson, A., \& Wängnerud, L. (2019). The effect of media sexism on women's political ambition: evidence from a worldwide study. Feminist Media Studies, 19 (4), 525-541. https://doi.org/10.1080/14680777.2 018.1468797.

Hooks, B. (2015). Feminism is for everybody: Passionate politics. London: New York: Routledge.

Huckin, T.N. (2005). Critical discourse analysis. In T.Miller, Functional approaches to written text: Classroom applications (pp. 78-92). Washington, D. C.: Office of English Language Programs, United States Department of State.

Ilhan Omar [Web page]. (2020). Retrieved from https://en.wikipedia.org/wiki/Ilhan_Omar.

Ilhan Omar [Website]. (n.d.). Retrieved from https://www.ilhanomar.com/.

Joly, D., \& Wadia, K. (2017). Muslim women and power: Political and civic engagement in West European societies. Palgrave MacMillan.

Meeks, L. (2013). He wrote, she wrote: Journalist gender, political office and campaign news. Journalism and Mass Communication Quarterly, 90 (1). 58-74.

O'Halloran, K.L. (2006). Multimodal discourse analysis: Systemic-functional perspectives. London: Continuum.

Made, P. A. (2008). Women in the news: Strengthening the voice and visibility of women in the African media's coverage of elections, politics and governance. Inter Press Service (IPS) Africa.

Ross, K. (2017). Gender, politics, news: A game of three sides. Wiley Blackwell.

Roth, A. L., \& Huff, M. (2019). Censored 2020: Through the looking glass: The top censored stories and media analysis of 2018-19. New York: Seven Stories Press.

Sanbonmatsu, K. (2002). Gender stereotypes and vote choice. American Journal of Political Science, 46 (1), 20-34. https://doi.org/10.2307/3088412.

Scruggs, N. (2012). Chapter 13 Somalia. In K. Malley-Morrison (Ed.), International perspectives on family violence and abuse: A cognitive ecological approach (pp. 219-238). Mahwah: Taylor and Francis.

Torronen, J. (2004). Zero-tolerance policing, the media and a local community. Journal of Scandinavian Studies in Criminology and Crime Prevention, 5 (1), 27-47.

Ward, O. (2016). Seeing double: Race, gender, and coverage of minority women's campaigns for the U. S. House of Representatives. Politics \& Gender, 12 (02), 317-343. https://doi.org/10.1017/s1743923x16000222.

Weingarten, B. (2020). American ingrate: Ilhan Omar and the progressive-Islamist takeover of the Democratic Party. New York: Bombadier Books.

Who makes the news? [Web page]. (2015). GMMP.Retrieved from http://cdn.agilitycms.com/who-makesthe-news/Imported/reports_2015/national/USA.pdf.

Received: May 1, 2020

Accepted: August 18, 2020

Author's information:

Desislava S. Cheshmedzhieva-Stoycheva - PhD in Philology, Associate Professor; d.stoycheva@shu.bg 


\section{Медиадискурс о женщинах в политике: первая темнокожая мусульманка в Конгрессе США}

\section{Д. С. Чешмеджиева-Стойчева}

Шуменский университет имени Епископа Константина Преславского, Болгария, 9700, Шумен, ул. Университетская, 115

Для цитирования: Cheshmedzhieva-Stoycheva, D. S. (2020). Media discourse on women in politics: The first Muslim woman of colour in US Congress. Медиалингвистика, 7 (4), 490-500. https://doi.org/10.21638/spbu22.2020.408

Статья является частью более развернутого исследования о представлении мусульманских женщин в средствах массовой информации. Основное внимание уделяется презентации Ильхан Омар, первой женщины-мусульманки в американском Конгрессе, рожденной в Сомали, а также последним публикациям об Омар, обсуждающим ее личную семейную жизнь и предполагаемый брак, в который она готова вступить со своим братом, чтобы дать ему возможность получить зеленую карту для проживания в США. Эта тема предполагает пересечение нескольких основных исследовательских областей: феминизм, исследование медиа и культурные исследования. Такое пересечение возможно, поскольку акцентируется предвзятое представление СМИ, призванное уменьшить реальную ценность женщины-политика, которая является носителем различных идентичностей, в частности гендерных, религиозных, этнических и классовых. Корпус исследования состоит из 42 статей, опубликованных в различных онлайнСМИ в течение четырех месяцев с января 2020 г. по апрель 2020 г. Утверждается что, во-первых, презентация Ильхан Омар носит гендерный характер, а во-вторых, она демонстрирует стереотипное представление о мусульманках как о покорных и молчаливых и с более низким статусом, чем мужчины, особенно в сфере, где доминируют мужчины, например в политике. Кроме того, утверждается, что, хотя Омар ломает существующие стереотипы о мусульманках, способ ее представления в средствах массовой информации фактически усиливает предвзятые идеи, которые она опровергает. Для доказательства вышеизложенного используются критический анализ дискурса и мультимодальный анализ, применяемый, когда речь идет о невербальной части медийного представления.

Ключевые слова: медиадискурс, мусульманки, политика, критический анализ дискурса, феминизм.

Статья поступила в редакцию 1 мая 2020 г;; рекомендована в печать 18 августа 2020 г.

Контактная информация:

Чешмеджиева-Стойчева Десислава Стоянова - канд. филол. наук, доц.; d.stoycheva@shu.bg 